\title{
Budgetary Trends of Uttarakhand Government: An Analysis of Almora District
}

\author{
Shivani Shah ${ }^{a^{*}}$, K.C. Joshi ${ }^{b}$, B.P. Singhalc \\ aDepartment of Commerce, Kumaun University, SSJ Campus Almora, Uttarakhand, India \\ E-mail id: shahshivani112@gmail.com \\ bDepartment of Commerce, Kumaun University, SSI Campus Almora, Uttarakhand, India \\ Email Id: kcjioshi1957@gmail.com \\ cFaculty of Commerce, Kumaun University, SSJ Campus Almora, Uttarakhand, India \\ EmailId:bpsinghal_com@refiffmail.com
}

\begin{abstract}
COVID-19 has shown us the need to review our budget allocation. Budget Analysis is a tool used to build public accountability and marginalize focus on public expenditure management and budget processes. It aims at influencing the distribution of federal funds and making them transparent. In this paper, budged allocations towards various sectors of a district economy are assessed. Objectives of the study are- 1 . To find out the distribution of funds to different areas of the economy 2. To assess deficiency/sufficiency/ over-sufficiency of funds for various heads, particularly in the COVID-19 Pandemic situation. Data for the last four years i.e., 2016-17 to 2019-20, is collected from government departments and other secondary sources for comparative and trend analysis. The study concludes that there is an uneven distribution of funds in the district. Some sectors like Medical and Health are underdeveloped still unable to utilize its funds entirely Other industries like Education and Energy can use their funds yet need an addition in allocation for development In the course of a pandemic it seems that rural development needs an increase in allocation to retain migrants back in the district and populate abandoned villages.
\end{abstract}

Key Words- COVID-19, Budget Allocation, District Economy,

PAPER/ARTICLE INFO

RECEIVED ON: 03/02/2020

ACCEPTED ON: 25/04/2020

Reference to this paper should be made as follows:

Shivani Shah, K.C. Joshi, B.P. Singhal (2020),

"Budgetary Trends of Uttarakhand Government: An Analysis of Almora District", Int. J. of Trade and Commerce-IIARTC, Vol. 9, No. 1 , pp. $230-244$ 
Budgetary Trends of Uttarakhand Government: An Analysis of Almora District

Shivani Shah, K.C. Joshi, B.P. Singhal

\section{INTRODUCTION}

With the 73rd and 74th amendments of the Constitution of India, decentralization of planning is emphasized, and the methodology of the district plan was changed. The Uttarakhand District Planning Committee Act, 2007 was passed by the Uttarakhand Legislative Assembly and assented by the Governor on July 13, 2007. The primary objective of the act is to constitute the District Planning Committee at the District Level for consolidation of plans prepared by the Panchayats and the Municipalities in the district and preparation of draft development plan for the community as a whole or the matters connected in addition to that or incidental to it.

The sequencing of the preparation of the district plan is as follows:

- Preparation of district vision, block vision, and gram panchayat level vision.

- Preparation of participatory plan involving Gram Sabha from Gram Panchayats to ZillaParishad.

- Preparation of plans by Urban Local Bodies.

- Consolidation of plans prepared by local bodies by District Planning Committees. ${ }^{1}$

Almora District, in the Kumaon region, is a district of Uttarakhand state, India, with its administrative headquarters located at Almora city. The area is the most suitable organizational unit for decentralized planning below the state level as it possesses the required heterogeneity and is small enough to undertake people in planning and implementation. To improve productivity, district planning is an essential tool. The district-level fund-flow and expenditure analysis is aimed at developing a comprehensive picture of resource flows and requirements at the district level.

\section{Literature REVIEW}

Annual plans of Uttarakhand state for many years have been reviewed for the grouping of expenditure heads and construction of significant leaders for analysis.

District Budget Analysis Study Including Funds Sources and DADPs Allocations in Kilosa and Chamwino District Councils (June 2014)-This report gives the findings for the study conducted in Kilosa and Chamwino districts in the respective regions of Morogoro and Dodoma in Tanzania. The study aimed at conducting District budget analysis for the district councils of Kilosa and Chamwino and identify funding sources for the district budget and its utilization, including DADPs allocations for the 2012/2013 and 2013/2014 financial years.

Jasmina, Thia. (2017). In her paper finds that, despite the increased government spending on education, the capacity of the local governments to manage and transform the financial resources into education outcomes is crucial. The education outcomes depend on not only the amount of spending but how well the money is spent.

Emmanuel Skoufias, Eric Strobl, and Thomas Tveit (March 2018) in their paper titled The Reallocation of District-Level Spending and Natural Disasters: Evidence from Indonesia stated that that district government spending is quite sensitive to the incidence of natural disasters at the local level.

Sharma Seema (May 2020) in her article 'Free power, easy loans: How Uttarakhand is trying to hold back locals who have returned from cities' has described reverse migration as an

${ }^{1}$ Manual for integrated district planning, New Delhi, Planning Commission, 2008 PP 51 - 132 
Budgetary Trends of Uttarakhand Government: An Analysis of Almora District

Shivani Shah, K.C. Joshi, B.P. Singhal

opportunity for Uttarakhand state. According to the article, As of April 23, a total of 59,360 people had returned to the ten hill districts in the country, according to government records and officials. Of these, 12,039 are from Pauri Garhwal and 9,303 from Almora - the two regions most affected by migration, according to an interim report released by the state's Rural Development and Migration Commission, or RDMC, on April 23.2

\section{Statement of the Problem}

The paper carries out the analysis of budgetary trends over time to illustrate the Government's commitment to addressing various issues in different sectors of the economy. The study will influence the allocation of public funds and make them transparent. The review will be useful to government /s, government officials, planners, researchers, academicians, etc.

4. OBJeCtives OF THE STUdY

a. To find out the allocation of funds to different sectors of the economy

b. To assess deficiency/sufficiency/ over-sufficiency of funds for various heads, particularly in the COVID-19 Pandemic situation.

\section{SCOPE OF THE STUdY}

The research is confined to the analysis of the Government allocations and actual spending by the various departments in district Almora for the last four years, i.e., FY 2016-17 to FY 2019-20.

\section{MeTHOdOlOgy ACCEPTED}

a. Source of Data:

The research is mainly based on secondary data, i.e., Financial Progress Report of various departments for the financial year 2016-17, 2017-18, 2018-19 and 2019-20 collected from Directorate of Economics and Statistics Planning Department, Government of Uttarakhand and other official publications of budget documents.

b. Tools For Analysis

Data collected is edited, summarized, and presented in suitable, tabular, and pictorial form. For analysis, percentage and trend analysis are done.

c. Limitations Of The Study

This study is limited to the Almora district in Uttarakhand. Hence the findings cannot be generalized.

\section{ANALYSIS}

The sources of funds are district plans (zilayojana), state plan (Rajyayojana), funds announced by central Government, and external grants. State plans and the central Government are the primary sources. Funds received under the above methods have been allocated under the following heads in the Financial Progress Report of various departments prepared by the Directorate of Economics and Statistics Planning Department, Government of Uttarakhand -

\footnotetext{
${ }^{2} \mathrm{http}$ // / www.uttarakhandpalayanayog.com/pdf/Inputs_for_supporting_reverse_migrants_after_covid-19_(Hindi).pdf $\frac{W / /}{\text { IJTC }}$ 
Budgetary Trends of Uttarakhand Government: An Analysis of Almora District

Shivani Shah, K.C. Joshi, B.P. Singhal

TABLE 1-Table showing all the minor heads used by the Government for budget allocation

\begin{tabular}{|c|c|c|c|c|c|c|c|}
\hline 1 & Roads And Bridges & $12(4)$ & DRDA & $17(5)$ & Minority Welfare & 28 & Tourism \\
\hline & /PMGSY/ADB/CR & $12 * 5)$ & $\begin{array}{l}\text { Administrative } \\
\text { Head }\end{array}$ & & & & \\
\hline 2 & Jal Nigam & $12 * 5)$ & (UBBDF) & $17(6)$ & $\begin{array}{l}\text { Handicapped } \\
\text { Welfare }\end{array}$ & 29 & $\begin{array}{l}\text { Economics } \\
\text { Statistics }\end{array}$ \\
\hline$\beta$ & JalSansthan & $12(6)$ & MLA Fund & $17(7)$ & AtalAwaasYojana & 30 & Sports \\
\hline 4 & Forest & $12(7)$ & $\begin{array}{l}\text { Pradhan } \\
\text { MantriAwaasYojana }\end{array}$ & $17(8)$ & SCP/TSP & 31 & Youth Welfare \\
\hline 5 & Electricity/RGGVY & $12(8)$ & MP Fund & $17(9)$ & Women Welfare & 32 & $\begin{array}{l}\text { Information } \\
\text { Department }\end{array}$ \\
\hline 6 & Alternate Energy & $12(9)$ & Credit & $17(10)$ & Gaura & 33 & Urban \\
\hline 7 & $\begin{array}{ll}\text { Private } & \text { Minor } \\
\text { Irrigation } & \end{array}$ & $12(10$ & $\mid \begin{array}{l}\text { Subsidy/New } \\
\text { Simplified Loan } \\
\text { Grant Scheme } \\
\text { Rural Pond Scheme }\end{array}$ & 18 & KanyadhanYojana & 34 & $\begin{array}{l}\text { Art And Culture } \\
\text { Department }\end{array}$ \\
\hline 8 & $\begin{array}{ll}\text { State } & \text { Irrigation } \\
(\text { Canal) } & \end{array}$ & $12(11)$ & $\begin{array}{l}\text { DeenDayalUpadhya } \\
\text { yGraminAwaasYoja } \\
\text { na }\end{array}$ & 19 & Horticulture & 35 & $\begin{array}{ll}\text { Total } & \text { Sanitation } \\
\text { Campaign(SWAJA } \\
\text { L) }\end{array}$ \\
\hline $8(1)$ & $\begin{array}{l}\text { Minor Irrigation } \\
\text { (Laghudaal) }\end{array}$ & 13 & $\begin{array}{l}\text { Community } \\
\text { Development/ } \\
\text { Grant To Blocks }\end{array}$ & 20 & Animal Husbandry & 36 & $\begin{array}{l}\text { Decentralized } \\
\text { Watershed } \\
\text { Development } \\
\text { Project (Rural) }\end{array}$ \\
\hline 9 & $\begin{array}{ll}\text { Medical } & \text { And } \\
\text { Health } & \end{array}$ & 14 & Primary Education & 21 & $\begin{array}{l}\text { Pisciculture } \\
\text { Fisheries }\end{array}$ & 37 & $\begin{array}{l}\text { Child Development } \\
\text { And Nutrition }\end{array}$ \\
\hline 10 & $\begin{array}{l}\text { Ayurvedic/Yunani } \\
\text { Treatment }\end{array}$ & 15 & $\begin{array}{l}\text { SarvaShikshaAbhiya } \\
\text { an }\end{array}$ & 22 & Dairy Development & 38 & Pooled Residence \\
\hline 11 & $\begin{array}{l}\text { Homeopathic } \\
\text { Treatment }\end{array}$ & 16 & $\begin{array}{l}\text { Secondary } \\
\text { Education }\end{array}$ & 23 & Co-Operative & 39 & Natural Disaster \\
\hline 12 & Rural Development & $17(!)$ & SC Welfare & 24 & Panchayati Raj & 40 & Employment \\
\hline $12(1)$ & Indira Awaas & $17(2)$ & $\begin{array}{l}\text { Backward Class } \\
\text { Welfare }\end{array}$ & 25 & $\begin{array}{l}\text { Rural And Micro } \\
\text { Industries }\end{array}$ & 39 & Natural Disaster \\
\hline $12(2)$ & $\begin{array}{l}\text { RashtriyaGraminYo } \\
\text { jgaar } \quad \text { Guarantee } \\
\text { Yojana }\end{array}$ & $17(3)$ & S.T. Welfare & 26 & $\begin{array}{l}\text { Khadi } \quad \text { Village } \\
\text { Industry }\end{array}$ & 40 & Employment \\
\hline $12(3)$ & NRLM & $17(4)$ & $\begin{array}{l}\text { Old Age } \\
\text { Pension/Family } \\
\text { Benefit Scheme }\end{array}$ & 27 & Silk Industry & & \\
\hline
\end{tabular}

For the sake of clarity and compactness, the above heads have been reduced as follows-

\begin{tabular}{|c|c|c|c|c|c|}
\hline 1 & Transport & 5 & $\begin{array}{l}\text { Health and Family } \\
\text { Welfare }\end{array}$ & 9 & $\begin{array}{l}\text { Industry, Agriculture } \\
\text { and Allied Activities }\end{array}$ \\
\hline 2 & $\begin{array}{l}\text { Water supply, Sanitation, } \\
\text { and Housing }\end{array}$ & 6 & Rural development & 10 & Miscellaneous \\
\hline 3 & Energy & 7 & $\begin{array}{l}\text { Education, Sports, Art, } \\
\text { and Culture }\end{array}$ & 11 & Urban development \\
\hline 4 & Irrigation & 8 & Social Welfare & & \\
\hline
\end{tabular}

The above heads have been used for analysis. 
Budgetary Trends of Uttarakhand Government: An Analysis of Almora District

Shivani Shah, K.C. Joshi, B.P. Singhal

The allocation under various heads over the last four years, i.e., from 2016-17 to 2019-20 has been done as follows-

TABLE 2:-Table showing increase/decrease percentage in actual expenditure

(all amounts in Lakhs rupees)

\begin{tabular}{|c|c|c|c|c|c|c|c|c|}
\hline & HEADS & 2016-17 & 2017-18 & $\begin{array}{c}\text { \% } \\
\text { increase/ } \\
\text { decrease }\end{array}$ & 2018-19 & $\begin{array}{c}\% \text { increase/ } \\
\text { decrease }\end{array}$ & $2019-20$ & $\begin{array}{c}\% \text { increase/ } \\
\text { decrease }\end{array}$ \\
\hline 1 & Transport & 13434.04 & 29896.19 & $122.54 \%$ & 20404.62 & $51.89 \%$ & 20416.41 & $51.98 \%$ \\
\hline 2 & $\begin{array}{l}\text { Water supply } \\
\text { Sanitation and } \\
\text { Housing }\end{array}$ & 6276.563 & 10403.71 & $65.75 \%$ & 8641.65 & $37.68 \%$ & 8811.76 & $40.39 \%$ \\
\hline 3 & Energy & 112.9738 & 138.11 & $22.25 \%$ & 430 & $280.62 \%$ & 536.00 & $374.45 \%$ \\
\hline 4 & Irrigation & 1551.52 & 951.55 & $-38.67 \%$ & 1108.51 & $-28.55 \%$ & 1118.95 & $-27.88 \%$ \\
\hline 5 & $\begin{array}{l}\text { Health and Family } \\
\text { Welfare }\end{array}$ & 1474.077 & 1778.08 & $20.62 \%$ & 1829.33 & $24.10 \%$ & 1927.02 & $30.73 \%$ \\
\hline 6 & Rural development & 5371.51 & 5853.921 & $8.98 \%$ & 6869.459 & $27.89 \%$ & 5579.84 & $3.88 \%$ \\
\hline 7 & $\begin{array}{l}\text { Education,Sports, Art } \\
\text { and Culture }\end{array}$ & 5814.138 & 7457.77 & $28.27 \%$ & 6467.463 & $11.24 \%$ & 3791.36 & $-34.79 \%$ \\
\hline 8 & Social Welfare & 11279.39 & 11371.69 & $0.82 \%$ & 11880.38 & $5.33 \%$ & 12996.16 & $15.22 \%$ \\
\hline 9 & $\begin{array}{l}\text { Industry,Agriculture } \\
\text { and Alied Activities }\end{array}$ & 2977.549 & 3645.668 & $22.44 \%$ & 5690.545 & $91.12 \%$ & 5256.91 & $76.55 \%$ \\
\hline 10 & Miscellaneous & 3933.201 & 5319.37 & $35.24 \%$ & 6286.98 & $59.84 \%$ & 7824.25 & $98.93 \%$ \\
\hline 11 & Urban development & - & - & - & - & - & 1285.92 & - \\
\hline & GRAND TOTAL & 52224.96 & 76816.06 & $47.09 \%$ & 69608.93 & $33.29 \%$ & 69544.57 & $33.16 \%$ \\
\hline
\end{tabular}

(Source -Directorate of Economics and Statistics Planning Department, Government of Uttarakhand)

TABLE 3:- Table showing share of each sector in the total outlay for each year

(All amounts in Lakhs rupees)

\begin{tabular}{|c|c|c|c|c|c|c|c|c|c|}
\hline & HEADS & 2016-17 & $\%$ of total & $2017-18$ & $\%$ of total & 2018-19 & $\%$ of total & 2019-20 & $\%$ of total \\
\hline 1 & Transport & 13434.04 & $25.72 \%$ & 29896.19 & $38.92 \%$ & 20404.617 & $29.31 \%$ & 20416.41 & $29.36 \%$ \\
\hline 2 & $\begin{array}{l}\text { Water supply, Sanitation } \\
\text { and Housing }\end{array}$ & 6276.563 & $12.02 \%$ & 10403.7096 & $13.54 \%$ & 8641.65 & $12.41 \%$ & 8811.76 & $12.67 \%$ \\
\hline 3 & Energy & 112.9738 & $0.22 \%$ & 138.11 & $0.18 \%$ & 430 & $0.62 \%$ & 536.00 & $0.77 \%$ \\
\hline 4 & Irrigation & 1551.52 & $2.97 \%$ & 951.55 & $1.24 \%$ & 1108.51 & $1.59 \%$ & 1118.95 & $1.61 \%$ \\
\hline 5 & $\begin{array}{l}\text { Health and Family } \\
\text { Welfare }\end{array}$ & 1474.077 & $2.82 \%$ & 1778.0799 & $2.31 \%$ & 1829.33 & $2.63 \%$ & 1927.02 & $2.77 \%$ \\
\hline 6 & Rural development & 5371.51 & $10.29 \%$ & 5853.92102 & $7.62 \%$ & 6869.45877 & $9.87 \%$ & 5579.84 & $8.02 \%$ \\
\hline 7 & $\begin{array}{l}\text { Education,Sports, Art and } \\
\text { Culture }\end{array}$ & 5814.138 & $11.13 \%$ & 7457.77 & $9.71 \%$ & 6467.463 & $9.29 \%$ & 3791.36 & $5.45 \%$ \\
\hline 8 & Social Welfare & 11279.39 & $21.60 \%$ & 11371.6864 & $14.80 \%$ & 11880.376 & $17.07 \%$ & 12996.16 & $18.69 \%$ \\
\hline 9 & $\begin{array}{l}\text { Industry, Agriculture and } \\
\text { Allied Activities }\end{array}$ & 2977.549 & $5.70 \%$ & 3645.6684 & $4.75 \%$ & 5690.54505 & $8.18 \%$ & 5256.91 & $7.56 \%$ \\
\hline 10 & Miscellaneous & 3933.201 & $7.53 \%$ & 5319.37 & $6.92 \%$ & 6286.98 & $9.03 \%$ & 7824.25 & $11.25 \%$ \\
\hline 11 & Urban Development & & & & & & & 1285.92 & $1.85 \%$ \\
\hline & GRAND TOTAL & 52224.96 & $100.00 \%$ & 76816.0553 & $100.00 \%$ & 69608.9298 & $100.00 \%$ & 69544.57 & $100.00 \%$ \\
\hline
\end{tabular}

(Source-Directorate of Economics and Statistics Planning Department, Government of Uttarakhand) 
7.1 Transport- Central Government has announced funds under Pradhan Mantri Gram SadakYojana (PMGSY) and Central Road Fund (CRF) to provide connectivity to unconnected habitations. The external grants are being received from the Asian Development Bank, which has funded various projects focusing on the development and maintenance of road infrastructure. The head transport includes expenses related to Road and bridges, PMGSY, ADB, CRF. The expenditure on this head is highest throughout the study period being $25.72 \%, 38.92 \%, 29.31 \%$, and $29.36 \%$ of the total spending in the years 2016-17, 2017-18, 2018-19 and 2019-20 respectively. Considering the expense of $2016-17$ as the base year, there is a $122.54 \%, 51.89 \%$, and $51.98 \%$ increase in 2017-18, 2018-19, and 2019-20 respectively, as shown in TABLE 2 . The reason behind the significant growth in 2017-18 is that the central Government has increased the funding under PMGSY and also the increase in grants by ADB. Uttarakhand has been ranked the best among states in the country for the construction of the maximum number of roads under the PMGSY during 2017-18. The state constructed a maximum of $1839 \mathrm{~km}$ roads under the PMGSY against the target of $1500 \mathrm{~km}$ set for the year 2017-18 under PMGSY, the connectivity roads also being built, due to which routes are constructed to all villages. ${ }^{3}$

7.2 Water Supply, sanitation, and Housing -This head includes Expenditure on Jal Nigam, JalSansthan, Swajal, AtalAwaasyojana, Decentralized Watershed Development Project (DWDP). The sources of funds are district plan, state plan, central govt, and outside grants. The overall expenditure in this head is $12.02 \%, 13.54 \%, 12.41 \%$, and $12.67 \%$, of the total spending in $2016-17$, 2017-18, 2018-19 and 2019-20 respectively (shown in TABLE 3). Taking 2016-17 as base year there is a $65.75 \%$ increase in the actual expenditure in 2017-18, But further, in 2018-19 the investment falls showing only $37.68 \%$ increase in real spending from the base year 2016-17 and.in 2019-20 there is an increase of $40.39 \%$ in 2019-20 as depicted by TABLE 2 .

TABLE 4:- Table showing \% of actual expenditure out of budget allotted to Water Supply Sanitation and Housing head in each year (all amounts in Lakhs rupees)

\begin{tabular}{|c|c|c|c|c|c|c|c|c|c|c|c|c|c|}
\hline \multirow{2}{*}{\begin{tabular}{|c|} 
S. \\
No.
\end{tabular}} & \multirow[b]{2}{*}{ Heads } & \multicolumn{3}{|c|}{ 2016-17 } & \multicolumn{3}{|c|}{ 2017-18 } & \multicolumn{3}{|c|}{ 2018-19 } & \multicolumn{3}{|c|}{ 2019-20 } \\
\hline & & $\begin{array}{c}\text { Allotte } \\
\text { d }\end{array}$ & spent & $\%$ & $\begin{array}{c}\text { Allotte } \\
\text { d }\end{array}$ & Spent & $\%$ & $\begin{array}{c}\text { Allotte } \\
\text { d }\end{array}$ & spent & $\%$ & $\begin{array}{c}\text { Allotte } \\
\text { d }\end{array}$ & Spent & $\%$ \\
\hline 1 & Jalnigam & 2846.87 & 2618.51 & $91.98 \%$ & 3752.47 & 3752.47 & $\begin{array}{c}100.00 \\
\%\end{array}$ & 3565.50 & 3301.10 & $92.58 \%$ & 5867.84 & 4962.78 & $84.58 \%$ \\
\hline 2 & JalSansthan & 867.84 & 812.29 & $93.60 \%$ & 949.45 & 937.29 & $98.72 \%$ & 1151.71 & 1067.60 & $92.70 \%$ & 1195.75 & 1174.23 & $98.20 \%$ \\
\hline 3 & $\begin{array}{l}\text { Total } \\
\text { SanitationCam } \\
\text { paign (Swajal) }\end{array}$ & 1395.86 & 1394.97 & $99.94 \%$ & 3425.89 & 3344.72 & $97.63 \%$ & 2146.78 & 1521.00 & $70.85 \%$ & 1103.39 & 946.84 & $85.81 \%$ \\
\hline 4 & $\begin{array}{llll}\mathrm{D} & \mathrm{W} & \mathrm{D} & \mathrm{P} \\
\text { (rural) } & & \end{array}$ & 1463.08 & 1441.44 & $98.52 \%$ & 2355.85 & 2355.82 & $\begin{array}{c}100.00 \\
\%\end{array}$ & 2734.29 & 2734.29 & $\begin{array}{c}100.00 \\
\%\end{array}$ & 1727.91 & 1727.91 & $\begin{array}{c}100.00 \\
\%\end{array}$ \\
\hline 5 & $\begin{array}{l}\text { AtalAwaasYoj } \\
\text { ana }\end{array}$ & 15.00 & 9.36 & $62.40 \%$ & 13.41 & 13.41 & $\begin{array}{c}100.00 \\
\%\end{array}$ & 17.66 & 17.66 & $\begin{array}{c}100.00 \\
\%\end{array}$ & 0.00 & 0.00 & $\begin{array}{c}\text { \#DIV/ } \\
0 !\end{array}$ \\
\hline & $\begin{array}{l}\text { Water supply } \\
\text { Sanitation and } \\
\text { Housing }\end{array}$ & 6588.64 & 6276.56 & $95.26 \%$ & $\begin{array}{c}10497.0 \\
7\end{array}$ & $\begin{array}{c}10403.7 \\
1\end{array}$ & $99.11 \%$ & 9615.94 & 8641.65 & $89.87 \%$ & 9894.89 & 8811.76 & $89.05 \%$ \\
\hline
\end{tabular}

(Source-Directorate of Economics and Statistics Planning Department, Government of Uttarakhand)

${ }^{3}$ https://economictimes.indiatimes.com/news/economy/infrastructure/uttarakhand-ranked-best-among-states-inpmgsy-official/articleshow/65810820.cms 
Budgetary Trends of Uttarakhand Government: An Analysis of Almora District

Shivani Shah, K.C. Joshi, B.P. Singhal

7.3 Energy- This head is inclusive of spending on Rajiv Gandhi GrameenVidyutyojna(RGGVY) and alternate energy sources. The allocation of funds towards energy is the lowest in all four years. The overall expenditure in this head is $0.22 \%, 0.18 \%, 0.62 \%$, and $0.77 \%$, of the total spending in 2016-17, 2017-18, 2018-19 and 2019-20 respectively. However, there is an increasing trend in the expenditure, i.e., $22.25 \%$ increase in $2017-18,280.62 \%$ hike in $2018-19$, and $374.45 \%$ rise in $2019-20$ as compared to the base year 2016-17 as shown in TABLE 2. The share of spending on energy in the total budget is also increasing year by year. The major part of the expenditure is on alternative energy. The state government is focusing on solar power projects for the economic development of hilly regions of the state. The spending on alternate energy has not fluctuated much. The drastic hike in 2018-19 and 2019=20 is due to the fund announced by the center for RGGVY.

TABLE 5:- Table showing \% of actual expenditure out of budget allotted to energy head in each year (all amounts in Lakhs rupees)

\begin{tabular}{|c|c|c|c|c|c|c|c|c|c|c|c|c|c|}
\hline \multirow{2}{*}{$\begin{array}{l}\text { S. } \\
\text { No. }\end{array}$} & \multirow{2}{*}{ Heads } & \multicolumn{3}{|c|}{ 2016-17 } & \multicolumn{3}{|c|}{ 2017-18 } & \multicolumn{3}{|c|}{ 2018-19 } & \multicolumn{3}{|c|}{ 2019-20 } \\
\hline & & \begin{tabular}{|c|}
$\begin{array}{c}\text { Allotte } \\
\text { d }\end{array}$ \\
\end{tabular} & Spent & $\%$ & $\begin{array}{c}\text { Allotte } \\
\text { d }\end{array}$ & Spent & $\%$ & $\begin{array}{c}\text { Allotte } \\
\text { d }\end{array}$ & spent & $\%$ & $\begin{array}{c}\text { Allotte } \\
\text { d }\end{array}$ & Spent & $\%$ \\
\hline 1 & $\begin{array}{l}\text { Electricity/RG } \\
\text { GVY }\end{array}$ & 0.02 & 0.02 & $\begin{array}{c}100.00 \\
\%\end{array}$ & 0.00 & 0.00 & $\begin{array}{c}\# \mathrm{DIV} / 0 \\
!\end{array}$ & 240.00 & 240.00 & $\begin{array}{c}100.00 \\
\%\end{array}$ & 344.00 & 344.00 & $\begin{array}{c}100.00 \\
\%\end{array}$ \\
\hline 2 & $\begin{array}{l}\text { Alternate } \\
\text { Energy }\end{array}$ & 112.95 & 112.95 & $\begin{array}{c}100.00 \\
\%\end{array}$ & 138.11 & 138.11 & $\begin{array}{c}100.00 \\
\%\end{array}$ & 190.00 & 190.00 & $\begin{array}{c}100.00 \\
\%\end{array}$ & 192.00 & 192.00 & $\begin{array}{c}100.00 \\
\%\end{array}$ \\
\hline & Energy & 112.97 & 112.97 & $\begin{array}{c}100.00 \\
\%\end{array}$ & 138.11 & 138.11 & $\begin{array}{c}100.00 \\
\%\end{array}$ & 430.00 & 430.00 & $\begin{array}{c}100.00 \\
\%\end{array}$ & 536.00 & 536.00 & $\begin{array}{c}100.00 \\
\%\end{array}$ \\
\hline
\end{tabular}

(Source -Directorate of Economics and Statistics Planning Department, Government of Uttarakhand)

7.4 Irrigation- This is one of the lowest spending sectors. The sector includes spending on minor private irrigation, state irrigation (canal), and laghudaal (minor flooding). The overall expenditure in this head is $2.97 \%, 1.24 \%, 1.59 \%$, and $1.61 \%$, of the total spending in 2016-17, 2017-18, 2018-19 and 2019-20 respectively. The expenditure on irrigation was decreased by $38.67 \%$ in $2017-18$, $28.55 \%$ in $2018-19$, and $27.88 \%$ in $2019-20$ when compared to the base year 2016-17, according to TABLE-2. Almora district has the maximum rain-fed area (i.e., $73576 \mathrm{ha}$ ) in the state ${ }^{4}$. It may be the reason why the Government is not spending much on irrigation schemes in the district.

TABLE 6:- Table showing \% of actual expenditure out of budget allotted to Irrigation head in each year (All amounts in Lakhs rupees)

\begin{tabular}{|c|c|c|c|c|c|c|c|c|c|c|c|c|c|}
\hline \multirow{2}{*}{$\begin{array}{l}\text { S. } \\
\text { No. }\end{array}$} & \multirow[t]{2}{*}{ Heads } & \multicolumn{3}{|c|}{ 2016-17 } & \multicolumn{3}{|c|}{ 2017-18 } & \multicolumn{3}{|c|}{ 2018-19 } & \multicolumn{3}{|c|}{ 2019-20 } \\
\hline & & Allotted & \begin{tabular}{|l|} 
Spent \\
\end{tabular} & $\%$ & Allotted & spent & $\%$ & Allotted & spent & $\%$ & Allotted & Spent & $\%$ \\
\hline 1 & \begin{tabular}{|l} 
Pvt. \\
minor \\
Irrigatio
\end{tabular} & 577.84 & 577.84 & $\begin{array}{c}100.00 \\
\%\end{array}$ & 114.00 & 114.00 & $\begin{array}{c}100.00 \\
\%\end{array}$ & 123.36 & 123.36 & $\begin{array}{c}100.00 \\
\%\end{array}$ & 155.19 & 118.98 & $76.66 \%$ \\
\hline 2 & $\begin{array}{l}\text { State } \\
\text { Irrigatio } \\
\text { n } \\
\text { (Canal) }\end{array}$ & 1282.36 & 917.68 & $71.56 \%$ & 866.87 & 783.44 & $90.38 \%$ & 936.67 & 927.60 & $99.03 \%$ & 1244.04 & 931.97 & $74.91 \%$ \\
\hline 3 & $\begin{array}{l}\text { Minor } \\
\text { Irrigatio } \\
\text { n }\end{array}$ & 56.00 & 56.00 & $\begin{array}{c}100.00 \\
\%\end{array}$ & 54.11 & 54.11 & $\begin{array}{c}100.00 \\
\%\end{array}$ & 57.55 & 57.55 & $\begin{array}{c}100.00 \\
\%\end{array}$ & 68.00 & 68.00 & $\begin{array}{c}100.00 \\
\%\end{array}$ \\
\hline & $\begin{array}{l}\text { Irrigatio } \\
n\end{array}$ & 1916.20 & 1551.52 & $80.97 \%$ & 1034.98 & 951.55 & $91.94 \%$ & 1117.58 & 1108.51 & $99.19 \%$ & 1467.23 & 1118.95 & $76.26 \%$ \\
\hline
\end{tabular}

(Source-Directorate of Economics and Statistics Planning Department, Government of Uttarakhand)

${ }^{4}$ Report on state specific action plan for Water sector Uttarakhand, page no. 32, http://nwm.gov.in/sites/default/files/Report_Draft-SSAP_Uttarakhand.pdf 
7.5 Health and family welfare - The head includes spending on medical and health, ayurvedic/Yunani treatment, and homeopathic treatment. Out of these three sectors, the last two have spent their funds to the fullest in all four years, but due to the medical and health Industry, the TABLE 7 shows that $77.48 \%, 86.85 \%, 78.71 \%$ and $78.23 \%$ of the total allotted funds were spent. The overall expenditure in this head is $2.62 \%, 2.31 \%, 2.63 \%$, and $2.77 \%$, of the total spending in 2016-17, 2017-18, 2018-19 and 2019-20 respectively. This sector has an increasing trend. There is a $20.62 \%$ increase in $2017-18$, a $24.10 \%$ increase in $2018-19$, and $30.73 \%$ increase in $2019-20$ as per TABLE 2.

TABLE 7:- Table showing $\%$ of actual expenditure out of budget allotted to health and family welfare head in each year

(All amounts in Lakhs rupees)

\begin{tabular}{|c|c|c|c|c|c|c|c|c|c|c|c|c|c|}
\hline \multirow{2}{*}{$\begin{array}{l}\text { S. } \\
\text { No. }\end{array}$} & \multirow[t]{2}{*}{ Heads } & \multicolumn{3}{|c|}{ 2016-17 } & \multicolumn{3}{|c|}{$2017-18$} & \multicolumn{3}{|c|}{ 2018-19 } & \multicolumn{3}{|c|}{ 2019-20 } \\
\hline & & \begin{tabular}{|c|}
$\begin{array}{c}\text { Allott } \\
\text { ed }\end{array}$ \\
\end{tabular} & Spent & $\%$ & $\begin{array}{c}\begin{array}{c}\text { Allott } \\
\text { ed }\end{array} \\
\text { ed }\end{array}$ & spent & $\%$ & $\begin{array}{c}\text { Allott } \\
\text { ed }\end{array}$ & spent & $\%$ & $\begin{array}{c}\text { Allott } \\
\text { ed }\end{array}$ & Spent & $\%$ \\
\hline \multirow[t]{2}{*}{1} & Medical and & 1837.7 & 1409.2 & 76.69 & 1969.0 & 1702.0 & 86.44 & 2258.4 & 1763.6 & 78.09 & 2380.9 & 1844.8 & 77.48 \\
\hline & Health & 1 & 8 & $\%$ & 4 & 9 & $\%$ & 5 & 1 & $\%$ & 6 & 1 & $\%$ \\
\hline \multirow[t]{2}{*}{2} & Ayurvedic/Y & 54.90 & 54.90 & $\begin{array}{c}100.00 \\
\%\end{array}$ & 59.06 & 59.06 & $\begin{array}{c}100.00 \\
\%\end{array}$ & 62.67 & 62.67 & $\begin{array}{c}100.00 \\
\%\end{array}$ & 72.21 & 72.21 & $\begin{array}{c}100.00 \\
\%\end{array}$ \\
\hline & $\begin{array}{l}\text { unani } \\
\text { Treatment }\end{array}$ & & & $\%$ & & & $\%$ & & & $\%$ & & & $\%$ \\
\hline \multirow[t]{4}{*}{3} & Homeopathi & 9.90 & 9.90 & 100.00 & 16.93 & 16.93 & 100.00 & 3.05 & 3.05 & 100.00 & 10.00 & 10.00 & 100.00 \\
\hline & c Treatment & & & $\%$ & & & $\%$ & & & $\%$ & & & $\%$ \\
\hline & Health and & 1902.5 & 1474.0 & 77.48 & 2045.0 & 1778.0 & 86.95 & 2324.1 & 1829.3 & 78.71 & 2463.1 & 1927.0 & 78.23 \\
\hline & $\begin{array}{l}\text { Family } \\
\text { Welfare }\end{array}$ & 1 & 8 & $\%$ & 3 & 8 & $\%$ & 7 & 3 & $\%$ & 7 & 2 & $\%$ \\
\hline
\end{tabular}

(Source -Directorate of Economics and Statistics Planning Department, Government of Uttarakhand)

7.6 Rural development - This includes expenditure on all the development schemes like Indira AawaasYojana, RashtriyaGraminYojgaar Guarantee Yojana (RGYGY), DRDA administrative head, Uttarakhand Border and Backward Area Development Fund (UBBDF), Pradhan MantriAaawaasYojana(PMAY), etc. and funds grants to mp and MLA for rural development. The overall expenditure in this head is $10.29 \%, 7.62 \%, 9.87 \%$, and $8.02 \%$, of the total expenditure in 2016-17, 2017-18, 2018-19 and 2019-20 respectively. The actual expenditure on rural development shows an increasing trend of up to 2018-19 and a fall in 2019-20. There is an $8.98 \%$ increase in 2017-18, a $27.89 \%$ increase in 2018-19. It reduces to a 3.88\% increase in 2019-20 as per TABLE 2. The reason behind this seems to be the decrease in funds allotted towards RGYGY and no allotment towards PMAY. Only $32.49 \%, 31.16 \%, 42.90 \%$, and $37.45 \%$ were spent out of the MLA fund in 4 years, respectively. Similarly, the M.P. fund was not even spent out fully, as shown in TABLE 8 below. In $2016-1768.16 \%$, in $2017-18$ only $28.72 \%$, 2018-19 $85.27 \%$ and in $2019-2085.48 \%$ of the allotted amount was spent. A large amount of budget allotted towards rural development remained unspent in all four years (TABLE 8). 
Budgetary Trends of Uttarakhand Government: An Analysis of Almora District

Shivani Shah, K.C. Joshi, B.P. Singhal

TABLE 8:- Table showing \% of actual expenditure out of budget allotted to Rural Development head in each year

(All amounts in Lakhs rupees)

\begin{tabular}{|c|c|c|c|c|c|c|c|c|c|c|c|c|c|}
\hline \multirow{2}{*}{$\begin{array}{c}\text { S. } \\
\text { No. }\end{array}$} & \multirow[t]{2}{*}{ Heads } & \multicolumn{3}{|c|}{ 2016-17 } & \multicolumn{3}{|c|}{ 2017-18 } & \multicolumn{3}{|c|}{ 2018-19 } & \multicolumn{3}{|c|}{ 2019-20 } \\
\hline & & \begin{tabular}{|c|}
$\begin{array}{c}\text { Allotte } \\
\mathrm{d}\end{array}$ \\
\end{tabular} & spent & $\%$ & $\begin{array}{c}\text { Allotte } \\
\mathrm{d}\end{array}$ & spent & $\%$ & Allotted & spent & $\%$ & $\begin{array}{c}\text { Allotte } \\
\text { d }\end{array}$ & Spent & $\%$ \\
\hline 1 & Indira awaas & 108.79 & 108.79 & $100.00 \%$ & 10.20 & 10.20 & $100.00 \%$ & 0.00 & 0.00 & $\begin{array}{c}\text { \#DIV /0 } \\
!\end{array}$ & 0.00 & 0.00 & $\begin{array}{c}\text { \#DIV /0 } \\
!\end{array}$ \\
\hline 2 & RGYGY & 3567.61 & 3561.40 & $99.83 \%$ & 3957.07 & 3950.18 & $99.83 \%$ & 3557.96 & 3551.48 & $99.82 \%$ & 2805.50 & 2805.50 & $100.00 \%$ \\
\hline 3 & NRLM & 15.86 & 14.36 & $90.56 \%$ & 82.55 & 79.86 & $96.74 \%$ & 145.15 & 143.59 & $98.92 \%$ & 152.69 & 133.07 & $87.15 \%$ \\
\hline 4 & $\begin{array}{l}\text { DRDA } \\
\text { Administrative } \\
\text { Head }\end{array}$ & 24.38 & 16.83 & $69.03 \%$ & 0.03 & 0.03 & $100.00 \%$ & 0.00 & 0.00 & $\begin{array}{c}\text { \#DIV / } 0 \\
!\end{array}$ & 0.00 & 0.00 & $\begin{array}{c}\text { \#DIV / } 0 \\
!\end{array}$ \\
\hline 5 & (UBBDF & 72.60 & 49.98 & $68.84 \%$ & 22.82 & 8.33 & $36.49 \%$ & 14.93 & 0.05 & $0.34 \%$ & 58.02 & 15.39 & $26.53 \%$ \\
\hline 6 & MLA Fund & 4177.71 & 1357.35 & $32.49 \%$ & 5070.35 & 1580.04 & $31.16 \%$ & 5740.69 & 2462.90 & $42.90 \%$ & 5528.38 & 2070.63 & $37.45 \%$ \\
\hline 7 & PMAY & 17.80 & 17.80 & $100.00 \%$ & 82.00 & 82.00 & $100.00 \%$ & 113.50 & 113.50 & $100.00 \%$ & 0.00 & 0.00 & $\begin{array}{c}\text { \#DIV / } 0 \\
!\end{array}$ \\
\hline 8 & MP Fund & 228.15 & 155.50 & $68.16 \%$ & 322.65 & 92.65 & $28.72 \%$ & 528.16 & 503.16 & $95.27 \%$ & 525.00 & 448.75 & $85.48 \%$ \\
\hline 9 & $\mid \begin{array}{ll}\text { Credit } & \text { Card } \\
\text { Subsidy/New } \\
\text { Simplified } \\
\text { Loan } \quad \text { Grant } \\
\text { Scheme }\end{array}$ & 2.35 & 2.30 & $97.71 \%$ & 0.53 & 0.53 & $100.00 \%$ & 0.00 & 0.00 & $\begin{array}{c}\text { \#DIV / } 0 \\
!\end{array}$ & 0.00 & 0.00 & $\begin{array}{c}\text { \#DIV /0 } \\
!\end{array}$ \\
\hline 10 & $\begin{array}{l}\text { DeenDayalUpa } \\
\text { dhyayGramin } \\
\text { AwaasYojana }\end{array}$ & 20.14 & 15.86 & $78.78 \%$ & 4.51 & 3.95 & $87.53 \%$ & 0.59 & 0.59 & $100.00 \%$ & 0.00 & 0.00 & $\begin{array}{c}\text { \#DIV / } 0 \\
!\end{array}$ \\
\hline 11 & $\begin{array}{l}\text { Community } \\
\text { development/ } \\
\text { Grant to } \\
\text { Blocks }\end{array}$ & 82.19 & 69.69 & $84.79 \%$ & 44.48 & 44.48 & $100.00 \%$ & 91.84 & 91.84 & $100.00 \%$ & 104.00 & 104.00 & $100.00 \%$ \\
\hline 12 & $\begin{array}{l}\text { Employment } \\
\text { Rural Pond } \\
\text { Scheme }\end{array}$ & $\begin{array}{c}1.65 \\
63.94\end{array}$ & $\begin{array}{l}1.65 \\
0.00\end{array}$ & $\left|\begin{array}{c}100.00 \% \\
0.00 \%\end{array}\right|$ & $\begin{array}{l}1.68 \\
63.96\end{array}$ & $\begin{array}{l}1.68 \\
0.00\end{array}$ & $\begin{array}{c}100.00 \% \\
0.00 \%\end{array}$ & 2.35 & 2.35 & $\begin{array}{c}100.00 \% \\
\text { \#DIV / } 0 \\
!\end{array}$ & 2.50 & 2.50 & $\begin{array}{c}100.00 \% \\
\text { \#DIV } / 0 \\
!\end{array}$ \\
\hline & $\begin{array}{l}\text { Rural } \\
\text { development }\end{array}$ & 8383.16 & 5371.51 & $64.08 \%$ & 9662.84 & 5853.92 & $60.58 \%$ & 10195.17 & 6869.46 & $67.38 \%$ & 9176.09 & 5579.84 & $60.81 \%$ \\
\hline
\end{tabular}

(Source-Directorate of Economics and Statistics Planning Department, Government of Uttarakhand)

7.7 Education, sports, arts, and culture - This head comprises of the expenditure related to primary education. Secondary Education, Sarva Shiksha Abhiyan, youth welfare/ provincial guard group (PRD), art and culture department, and sports. The overall expenditure in this head is $11.13 \%$ (FIGURE 1),9.71\%(FIGURE 2), 9.29\%(FIGURE 3), and 5.45\%(FIGURE 4), of the total expenditure in 2016-17, 2017-18, 2018-19 and 2019-20 respectively. The spending on SarvaShikshaAbhiyan is more than primary and secondary education. The actual spending is fluctuating every year, as shown in TABLE 2. It is highest in 2017-18 (Rs.7457.77 lacs) and lowest in 2019-20 (Rs. 3791.36 lacs). 
Budgetary Trends of Uttarakhand Government: An Analysis of Almora District

Shivani Shah, K.C. Joshi, B.P. Singhal

TABLE 9:- Table showing $\%$ of actual expenditure out of budget allotted to education, sports, arts, and culture head in each year

(All amounts in Lakhs rupees)

\begin{tabular}{|c|c|c|c|c|c|c|c|c|c|c|c|c|c|}
\hline \multirow{2}{*}{$\begin{array}{l}\text { S. } \\
\text { No. }\end{array}$} & \multirow[t]{2}{*}{ Heads } & \multicolumn{3}{|c|}{ 2016-17 } & \multicolumn{3}{|c|}{ 2017-18 } & \multicolumn{3}{|c|}{ 2018-19 } & \multicolumn{3}{|c|}{$2019-20$} \\
\hline & & \begin{tabular}{|c|} 
Allotte \\
d
\end{tabular} & spent & $\%$ & $\begin{array}{c}\text { Allotte } \\
\text { d }\end{array}$ & spent & $\%$ & $\begin{array}{c}\text { Allotte } \\
\text { d }\end{array}$ & spent & $\%$ & $\begin{array}{c}\text { Allotte } \\
\text { d }\end{array}$ & Spent & $\%$ \\
\hline 1 & $\begin{array}{l}\text { Primary } \\
\text { Education }\end{array}$ & $\begin{array}{c}1254.8 \\
7\end{array}$ & $\begin{array}{c}1162.5 \\
7\end{array}$ & $92.64 \%$ & 1336.2 & 1280.2 & $95.81 \%$ & $\begin{array}{c}1045.9 \\
7\end{array}$ & 984.28 & $94.10 \%$ & $\begin{array}{c}1087.6 \\
3\end{array}$ & $\begin{array}{c}1076.0 \\
5\end{array}$ & $98.94 \%$ \\
\hline 2 & $\begin{array}{l}\text { SarvaShiksh } \\
\text { aAbhiyaan }\end{array}$ & $\begin{array}{c}3386.4 \\
9\end{array}$ & $\begin{array}{c}3386.4 \\
9\end{array}$ & $\begin{array}{c}100.00 \\
\%\end{array}$ & $\begin{array}{c}5313.8 \\
3\end{array}$ & $\begin{array}{c}5251.2 \\
1\end{array}$ & $98.82 \%$ & $\begin{array}{c}4496.9 \\
1\end{array}$ & $\begin{array}{c}4448.3 \\
2\end{array}$ & $98.92 \%$ & $\begin{array}{c}1679.0 \\
7\end{array}$ & $\begin{array}{c}1548.0 \\
9\end{array}$ & $92.20 \%$ \\
\hline 3 & $\begin{array}{l}\text { Secondary } \\
\text { Education }\end{array}$ & 878.47 & 878.47 & $\begin{array}{c}100.00 \\
\%\end{array}$ & 501.21 & 501.21 & $\begin{array}{c}100.00 \\
\%\end{array}$ & 664.43 & 647.60 & $97.47 \%$ & 861.46 & 765.72 & $88.89 \%$ \\
\hline 4 & Sports & 106.34 & 106.34 & $\begin{array}{c}100.00 \\
\%\end{array}$ & 80.67 & 80.67 & $\begin{array}{c}100.00 \\
\%\end{array}$ & 75.95 & 75.95 & $\begin{array}{c}100.00 \\
\%\end{array}$ & 79.50 & 79.50 & $\begin{array}{c}100.00 \\
\%\end{array}$ \\
\hline 5 & $\begin{array}{l}\text { Youth } \\
\text { Welfare }\end{array}$ & 263.86 & 259.40 & $98.31 \%$ & 287.28 & 287.28 & $\begin{array}{c}100.00 \\
\%\end{array}$ & 290.74 & 290.74 & $\begin{array}{c}100.00 \\
\%\end{array}$ & 300.00 & 300.00 & $\begin{array}{c}100.00 \\
\%\end{array}$ \\
\hline 6 & $\begin{array}{l}\text { Art and } \\
\text { culture } \\
\text { Department }\end{array}$ & 20.86 & 20.86 & $\begin{array}{c}100.00 \\
\%\end{array}$ & 57.14 & 57.14 & $\begin{array}{c}100.00 \\
\%\end{array}$ & 20.57 & 20.57 & $\begin{array}{c}100.00 \\
\%\end{array}$ & 22.00 & 22.00 & $\begin{array}{c}100.00 \\
\%\end{array}$ \\
\hline & $\begin{array}{l}\text { Education,S } \\
\text { ports ,Art } \\
\text { and Culture }\end{array}$ & $\begin{array}{c}5910.8 \\
9\end{array}$ & $\begin{array}{c}5814.1 \\
4\end{array}$ & $98.36 \%$ & $\begin{array}{c}7576.3 \\
9\end{array}$ & $\begin{array}{c}7457.7 \\
7\end{array}$ & $98.43 \%$ & $\begin{array}{c}6594.5 \\
7\end{array}$ & $\begin{array}{c}6467.4 \\
6\end{array}$ & $98.07 \%$ & $\begin{array}{c}4029.6 \\
6\end{array}$ & $\begin{array}{c}3791.3 \\
6\end{array}$ & $94.09 \%$ \\
\hline
\end{tabular}

(Source-Directorate of Economics and Statistics Planning Department, Government of Uttarakhand)

7.8 Social welfare - This sector is the second-highest spending sector after transport. The Industry is inclusive of various welfare schemes relating to multiple sections of society, namely scheduled castes, scheduled tribe, backward classes, minorities, old age people, handicapped, soldiers, women, and children. It also includes schemes like Gaura Devi KanyadhanYojana and disaster management. The overall expenditure in this head is $21.60 \%, 14.80 \%, 17.07 \%$, and $18.69 \%$, of the total spending in 2016-17, 2017-18, 2018-19 and 2019-20, respectively (TABLE 3). Also, this sector is showing an increasing trend from Rs 11279.39 lacs in 2016-17 to Rs 12996.16 lacs in 2019-20, which is a $15.22 \%$ increase (TABLE 2 ). 
Budgetary Trends of Uttarakhand Government: An Analysis of Almora District

Shivani Shah, K.C. Joshi, B.P. Singhal

TABLE 10:- Table showing \% of actual expenditure out of budget allotted to Social welfare head in each year (All amounts in Lakhs rupees)

\begin{tabular}{|c|c|c|c|c|c|c|c|c|c|c|c|c|c|}
\hline \multirow{2}{*}{$\begin{array}{l}\text { S. } \\
\text { No. }\end{array}$} & \multirow[t]{2}{*}{ Heads } & \multicolumn{3}{|c|}{ 2016-17 } & \multicolumn{3}{|c|}{ 2017-18 } & \multicolumn{3}{|c|}{ 2018-19 } & \multicolumn{3}{|c|}{ 2019-20 } \\
\hline & & \begin{tabular}{|c} 
Allotte \\
d
\end{tabular} & spent & $\%$ & $\begin{array}{c}\text { Allotte } \\
\text { d }\end{array}$ & Spent & $\%$ & $\begin{array}{c}\text { Allotte } \\
\text { d }\end{array}$ & spent & $\%$ & $\begin{array}{c}\text { Allotte } \\
\text { d }\end{array}$ & Spent & $\%$ \\
\hline 1 & $\frac{\text { SC }}{\text { Welfare }}$ & 431.11 & 247.95 & $57.51 \%$ & 406.13 & 398.68 & $98.17 \%$ & 478.36 & 452.02 & $94.49 \%$ & 941.06 & 556.86 & $59.17 \%$ \\
\hline 2 & $\begin{array}{l}\text { Backward } \\
\text { Class } \\
\text { Welfare }\end{array}$ & 68.29 & 5.17 & $7.57 \%$ & 42.64 & 42.62 & $99.95 \%$ & 21.17 & 17.21 & $81.29 \%$ & 32.48 & 32.40 & $99.75 \%$ \\
\hline 3 & $\begin{array}{l}\text { S.T. } \\
\text { Welfare }\end{array}$ & 0.00 & 0.00 & $\begin{array}{c}\text { \#DIV/ } \\
0 !\end{array}$ & 19.85 & 17.41 & $87.71 \%$ & 10.01 & 1.87 & $18.68 \%$ & 5.52 & 1.11 & $20.11 \%$ \\
\hline 4 & $\begin{array}{l}\text { Old age } \\
\text { Pension/Fa } \\
\text { mily } \\
\text { Benefit } \\
\text { Scheme }\end{array}$ & 5109.92 & 5049.81 & $98.82 \%$ & 6088.85 & 5595.67 & $91.90 \%$ & 5635.48 & 5635.42 & $\begin{array}{c}100.00 \\
\%\end{array}$ & 6319.85 & 6292.86 & $99.57 \%$ \\
\hline 5 & $\begin{array}{l}\text { Minority } \\
\text { Welfare }\end{array}$ & 274.47 & 274.43 & $99.99 \%$ & 0.87 & 0.79 & $90.80 \%$ & 0.00 & 0.00 & $\begin{array}{c}\text { \#DIV/ } \\
0 !\end{array}$ & 0.00 & 0.00 & $\begin{array}{c}\text { \#DIV / } \\
0 !\end{array}$ \\
\hline 6 & $\begin{array}{l}\text { Handicapp } \\
\text { ed Welfare }\end{array}$ & 878.96 & 661.03 & $75.21 \%$ & 692.58 & 690.60 & $99.71 \%$ & 784.98 & 784.95 & $\begin{array}{c}100.00 \\
\%\end{array}$ & 755.17 & 754.51 & $99.91 \%$ \\
\hline 7 & $\begin{array}{l}\text { soldier } \\
\text { welfare }\end{array}$ & 1.87 & 1.85 & $99.19 \%$ & 0.00 & 0.00 & $\begin{array}{c}\text { \#DIV/ } \\
0 !\end{array}$ & 0.00 & 0.00 & $\begin{array}{c}\text { \#DIV/ } \\
0 !\end{array}$ & & & $\begin{array}{c}\# \mathrm{DIV} / \\
0 !\end{array}$ \\
\hline 8 & SCP/TSP & 253.03 & 253.03 & $\begin{array}{c}100.00 \\
\%\end{array}$ & 266.69 & 133.34 & $50.00 \%$ & 419.12 & 419.12 & $\begin{array}{c}100.00 \\
\%\end{array}$ & 196.04 & 196.04 & $\begin{array}{c}100.00 \\
\%\end{array}$ \\
\hline 9 & $\begin{array}{l}\text { Women } \\
\text { Welfare }\end{array}$ & 1540.35 & 1537.75 & $99.83 \%$ & 1496.15 & 1496.08 & $\begin{array}{c}100.00 \\
\%\end{array}$ & 1919.34 & 1835.58 & $95.64 \%$ & 1843.58 & 1842.42 & $99.94 \%$ \\
\hline 10 & $\begin{array}{l}\text { Gaura } \\
\text { Devi } \\
\text { Kanyadha } \\
\text { nYojana }\end{array}$ & 645.00 & 645.00 & $\begin{array}{c}100.00 \\
\%\end{array}$ & 103.50 & 103.00 & $99.52 \%$ & 210.50 & 210.50 & $\begin{array}{c}100.00 \\
\%\end{array}$ & 0.00 & 0.00 & $\begin{array}{c}\text { \#DIV / } \\
0 !\end{array}$ \\
\hline 11 & $\begin{array}{l}\text { Child } \\
\text { Developm } \\
\text { ent and } \\
\text { Nutrition }\end{array}$ & 2436.51 & 2166.42 & $88.91 \%$ & 2491.32 & 2227.80 & $89.42 \%$ & 2712.61 & 2137.80 & $78.81 \%$ & 3063.66 & 2658.19 & $86.77 \%$ \\
\hline 12 & $\begin{array}{l}\text { Natural } \\
\text { Disaster } \\
\text { Social }\end{array}$ & $\begin{array}{l}800.00 \\
\mathbf{1 2 4 3 9 . 5}\end{array}$ & $\begin{array}{l}436.95 \\
11279.3\end{array}$ & $\begin{array}{l}54.62 \% \\
90.67 \%\end{array}$ & $\begin{array}{l}700.00 \\
\mathbf{1 2 3 0 8 . 5}\end{array}$ & 665.70 & $95.10 \%$ & 700.00 & 385.91 & $\begin{array}{l}55.13 \% \\
92.16 \%\end{array}$ & $\begin{array}{l}750.00 \\
13907.3\end{array}$ & $\begin{array}{l}661.77 \\
12996.1\end{array}$ & $\begin{array}{l}88.24 \% \\
93.45 \%\end{array}$ \\
\hline & Welfare & 0 & 9 & & 8 & 9 & & 7 & 8 & & 6 & 6 & \\
\hline
\end{tabular}

(Source-Directorate of Economics and Statistics Planning Department, Government of Uttarakhand)

7.9 Industry, Agriculture, and allied activities- This sector includes spending relating to agriculture, horticulture, animal husbandry, pisciculture, dairy development, cooperative, rural and micro industries, khadi village industries, silk industries, tourism industries, and forest department. The overall expenditure in this head is $5.70 \%, 4.75 \%, 8.18 \%$, and $7.56 \%$, of the total spending in 2016-17, 2017-18, 2018-19 and 2019-20 respectively. The expenditure was highest in 2018-19, i.e., Rs.5690.545 lacs and lowest in 2016-17, i.e., ,Rs-2977.549 lacs (TABLE 2). The horticulture department is unable to utilize the budget to its fullest, as shown in TABLE 11 below. 
TABLE 11:- Table showing \% of actual expenditure out of budget allotted to Industry, agriculture and allied activities head in each year (All amounts in Lakhs rupees)

\begin{tabular}{|c|c|c|c|c|c|c|c|c|c|c|c|c|c|}
\hline \multirow{2}{*}{$\begin{array}{l}\text { S. } \\
\text { No. }\end{array}$} & \multirow[t]{2}{*}{ Heads } & \multicolumn{3}{|c|}{ 2016-17 } & \multicolumn{3}{|c|}{ 2017-18 } & \multicolumn{3}{|c|}{ 2018-19 } & \multicolumn{3}{|c|}{ 2019-20 } \\
\hline & & $\begin{array}{c}\text { Allotte } \\
\text { d }\end{array}$ & Spent & $\%$ & $\begin{array}{c}\text { Allotte } \\
\text { d }\end{array}$ & Spent & $\%$ & $\begin{array}{c}\text { Allotte } \\
\mathrm{d}\end{array}$ & Spent & $\%$ & $\begin{array}{c}\text { Allotte } \\
\text { d }\end{array}$ & Spent & $\%$ \\
\hline 1 & Agric & 1448.6 & 1364.8 & $94.21 \%$ & 1303.8 & 1219.3 & $93.52 \%$ & 1814.8 & 1622.3 & $89.39 \%$ & 1605.6 & 1551.3 & 96.62 \\
\hline & & 6 & 3 & & 3 & 2 & & 4 & 0 & & 0 & 1 & \\
\hline 2 & Horticulture & 296.65 & 252.85 & $85.24 \%$ & 226.28 & 171.64 & $75.85 \%$ & 278.17 & 221.77 & $79.72 \%$ & 342.97 & 292.98 & $85.42 \%$ \\
\hline 3 & \begin{tabular}{|l} 
Animal \\
Husbandary
\end{tabular} & 215.56 & 206.23 & $95.67 \%$ & 349.65 & 348.82 & $99.76 \%$ & 341.06 & 340.38 & $99.80 \%$ & 436.88 & 414.45 & $94.87 \%$ \\
\hline 4 & $\begin{array}{l}\text { Pisciculture } \\
\text { fisheries }\end{array}$ & 22.92 & 22.92 & $\begin{array}{c}100.00 \\
\%\end{array}$ & 15.81 & 8.99 & $56.85 \%$ & 28.09 & 28.09 & $\begin{array}{c}100.00 \\
\%\end{array}$ & 41.45 & 41.45 & $\begin{array}{c}100.00 \\
\%\end{array}$ \\
\hline 5 & \begin{tabular}{|l} 
Dairy \\
Development
\end{tabular} & 209.81 & 209.81 & $\begin{array}{c}100.00 \\
\%\end{array}$ & 239.81 & 239.81 & $\begin{array}{c}100.00 \\
\%\end{array}$ & 417.45 & 416.67 & $99.81 \%$ & 454.25 & 442.96 & $97.52 \%$ \\
\hline 6 & Co-operative & 107.00 & 107.00 & $\begin{array}{c}100.00 \\
\%\end{array}$ & 90.00 & 90.00 & $\begin{array}{c}100.00 \\
\%\end{array}$ & 100.00 & 100.00 & $\begin{array}{c}100.00 \\
\%\end{array}$ & 90.00 & 90.00 & $\begin{array}{c}100.00 \\
\%\end{array}$ \\
\hline 7 & $\mid \begin{array}{l}\text { Rural and } \\
\text { micro } \\
\text { industries }\end{array}$ & 161.14 & 161.12 & $99.99 \%$ & 25.85 & 25.85 & $\begin{array}{c}100.00 \\
\%\end{array}$ & 21.42 & 21.42 & $\begin{array}{c}100.00 \\
\%\end{array}$ & 7.00 & 7.00 & $\begin{array}{c}100.00 \\
\%\end{array}$ \\
\hline 8 & $\begin{array}{l}\text { Khadi Village } \\
\text { Industry }\end{array}$ & 33.66 & 33.66 & $\begin{array}{c}100.00 \\
\%\end{array}$ & 28.95 & 28.95 & $\begin{array}{c}100.00 \\
\%\end{array}$ & 20.55 & 20.55 & $\begin{array}{c}100.00 \\
\%\end{array}$ & 25.00 & 25.00 & $\begin{array}{c}100.00 \\
\%\end{array}$ \\
\hline 9 & silk Industry & 19.26 & 19.26 & $\begin{array}{c}100.00 \\
\%\end{array}$ & 17.74 & 16.14 & $90.98 \%$ & 19.88 & 19.88 & $\begin{array}{c}100.00 \\
\%\end{array}$ & 21.47 & 21.47 & $\begin{array}{c}100.00 \\
\%\end{array}$ \\
\hline 10 & Tourism & 196.64 & 196.64 & $\mid \begin{array}{c}100.00 \\
\%\end{array}$ & $\begin{array}{c}1151.2 \\
7\end{array}$ & $\begin{array}{c}1151.2 \\
7\end{array}$ & $\begin{array}{c}100.00 \\
\%\end{array}$ & $\begin{array}{c}1313.3 \\
6\end{array}$ & $\begin{array}{c}1313.3 \\
6\end{array}$ & $\begin{array}{c}100.00 \\
\%\end{array}$ & $\begin{array}{c}1042.7 \\
2\end{array}$ & $\begin{array}{c}1042.7 \\
2\end{array}$ & $\begin{array}{c}100.00 \\
\%\end{array}$ \\
\hline 11 & $\begin{array}{l}\text { Forest } \\
\text { Department }\end{array}$ & 405.23 & 403.23 & $99.51 \%$ & 351.98 & 344.88 & $97.98 \%$ & $\begin{array}{c}1586.1 \\
3\end{array}$ & $\begin{array}{c}1586.1 \\
3\end{array}$ & $\begin{array}{c}100.00 \\
\%\end{array}$ & $\begin{array}{c}1606.7 \\
8\end{array}$ & $\begin{array}{c}1327.5 \\
6\end{array}$ & $82.62 \%$ \\
\hline & $\begin{array}{l}\text { Industry,Agri } \\
\text { culture and } \\
\text { Alied } \\
\text { Activities }\end{array}$ & $\begin{array}{c}3116.5 \\
3\end{array}$ & $\begin{array}{c}2977.5 \\
5\end{array}$ & $95.54 \%$ & $\begin{array}{c}3801.1 \\
7\end{array}$ & $\begin{array}{c}3645.6 \\
7\end{array}$ & $95.91 \%$ & $\begin{array}{c}5940.9 \\
5\end{array}$ & $\begin{array}{c}5690.5 \\
5\end{array}$ & $95.79 \%$ & $\begin{array}{c}5674.1 \\
1\end{array}$ & $\begin{array}{c}5256.9 \\
1\end{array}$ & $92.65 \%$ \\
\hline
\end{tabular}

(Source-Directorate of Economics and Statistics Planning Department, Government of Uttarakhand)

7.10 Miscellaneous- The miscellaneous head contains departments like economics\& statistics, information, Panchayati Raj, and pooled residence. The overall expenditure in this head is $7.53 \%$, $6.92 \%, 9.03 \%$, and $11.25 \%$, of the total spending in 2016-17, 2017-18, 2018-19 and 2019-20 respectively. Spending shows an increasing trend. It has increased $98.93 \%$ from 2016-17(Rs. 3933.201 lacs) to 2019-20 (Rs 7824.25 lacs) as per TABLE 2 
Budgetary Trends of Uttarakhand Government: An Analysis of Almora District

Shivani Shah, K.C. Joshi, B.P. Singhal

TABLE 12:- Table showing \% of actual expenditure out of budget allotted to Miscellaneous head in each year (All amounts in Lakhs rupees)

\begin{tabular}{|c|c|c|c|c|c|c|c|c|c|c|c|c|c|}
\hline \multirow{2}{*}{\begin{tabular}{|l} 
S. \\
No
\end{tabular}} & \multirow[t]{2}{*}{ Heads } & \multicolumn{3}{|c|}{ 2016-17 } & \multicolumn{3}{|c|}{$2017-18$} & \multicolumn{3}{|c|}{ 2018-19 } & \multicolumn{3}{|c|}{ 2019-20 } \\
\hline & & $\begin{array}{c}\text { Allotte } \\
\text { d }\end{array}$ & Spent & $\%$ & $\begin{array}{c}\text { Allotte } \\
\text { d }\end{array}$ & Spent & $\%$ & $\begin{array}{c}\text { Allotte } \\
\text { d }\end{array}$ & Spent & $\%$ & $\begin{array}{c}\text { Allotte } \\
\text { d }\end{array}$ & Spent & $\%$ \\
\hline 1 & $\begin{array}{l}\text { Economics } \\
\text { and } \\
\text { Statistics }\end{array}$ & 33.96 & 33.96 & $\begin{array}{c}100.00 \\
\%\end{array}$ & 11.57 & 11.57 & $\begin{array}{c}100.00 \\
\%\end{array}$ & 14.00 & 14.00 & $\begin{array}{c}100.00 \\
\%\end{array}$ & 16.00 & 16.00 & $\begin{array}{c}100.00 \\
\%\end{array}$ \\
\hline 2 & $\begin{array}{c}\text { Information } \\
\text { Departmen } \\
t\end{array}$ & 12.50 & 12.50 & $\begin{array}{c}100.00 \\
\%\end{array}$ & 15.51 & 15.51 & $\begin{array}{c}100.00 \\
\%\end{array}$ & 16.50 & 16.50 & $\begin{array}{c}100.00 \\
\%\end{array}$ & 16.50 & 16.50 & $\begin{array}{c}100.00 \\
\%\end{array}$ \\
\hline 3 & $\begin{array}{c}\text { Pooled } \\
\text { Residence }\end{array}$ & 37.10 & 26.52 & $71.48 \%$ & 101.61 & 101.61 & $\begin{array}{c}100.00 \\
\%\end{array}$ & 88.73 & 88.73 & $\begin{array}{c}100.00 \\
\%\end{array}$ & 182.12 & 173.81 & $95.44 \%$ \\
\hline 4 & $\begin{array}{c}\text { Panchayati } \\
\text { Raj }\end{array}$ & 3860.22 & $\begin{array}{c}3860.2 \\
2\end{array}$ & $\begin{array}{c}100.00 \\
\%\end{array}$ & 5190.68 & $\mid \begin{array}{c}5190.6 \\
8\end{array}$ & $\begin{array}{c}100.00 \\
\%\end{array}$ & 6167.75 & $\begin{array}{c}6167.7 \\
5\end{array}$ & $\begin{array}{c}100.00 \\
\%\end{array}$ & 7617.94 & $\begin{array}{c}7617.9 \\
4\end{array}$ & $\begin{array}{c}100.00 \\
\%\end{array}$ \\
\hline & $\begin{array}{c}\text { Miscellaneo } \\
\text { us }\end{array}$ & 3943.78 & $\begin{array}{c}3933.2 \\
0\end{array}$ & $99.73 \%$ & 5319.37 & $\begin{array}{c}5319.3 \\
7\end{array}$ & $\begin{array}{c}100.00 \\
\%\end{array}$ & 6286.98 & $\begin{array}{c}6286.9 \\
8\end{array}$ & $\begin{array}{c}100.00 \\
\%\end{array}$ & 7832.56 & $\begin{array}{c}7824.2 \\
5 \\
\end{array}$ & $99.89 \%$ \\
\hline
\end{tabular}

(Source-Directorate of Economics and Statistics Planning Department, Government of Uttarakhand)

7.11 Urban development - In 2019-20, Rs.1697.78 lacs was allocated towards urban growth, out of which Rs 1285.92 lacs was spent, i.e., $75.74 \%$. It constituted $1.85 \%$ of total actual Expenditure (TABLE 3). The budget was allocated from the state plan, and the Central Government also announced a sum for the same.

\section{CONCLUSION AND SUGgeSTIONS}

The analysis has indicated that some sectors have spent fewer amounts compared to the amount received, while others have managed to pay $100 \%$ of the released budget. The overall; trend of funds allocated to the district is fluctuating. It is highest in 2017-18, as shown in TABLE 2. Transport and Social Welfare are significant sectors that are getting almost half of the total funds allocated, as shown in TABLE 3.Thus, it can be concluded that budgetary trends of the district are fluctuating. The budget is sufficiently allocated towards Transport, Water Supply, Sanitation and Housing, Irrigation, Social Welfare, and Miscellaneous sector. Budget utilization is inefficient by sectors like Rural Development, Medical and Health, Urban Development, and Education sector. The budget allocated towards Energy and Industry, Agriculture, and Allied activities seem to be insufficient.

The present study puts forward the following recommendations as to the necessary steps in filling the gaps experienced in the district budget allocation and utilization:-

- The transport sector has been receiving the highest resources out of all the other areas. Still, the roads and bridges in the district are not in excellent condition. It is suggested that the Government should allocate funds towards the maintenance of existing roads and bridges and also for proper quality control of new road constructions to reduce further maintenance costs

- The energy sector has been utilizing its funds to the fullest. This sector has a lot of potentials to explore, for this budget should be sufficiently increased. 
- Due to COVID-19 reverse migration is witnessed in the district, the Government should provide opportunities for the locals in the rural areas by increasing the budget allocations for rural development schemes and also for the industries, agriculture and allied activities in the district to strengthen the local suppliers to resolve the pandemic crisis. The funds can be used for strategic promotion for encouraging the locals to be self-reliant and investing time and resources in this sector.

- The fund Allotted for rural development should be fully utilized by the representative of the Government (M.P. and MLA), or the said funds should be reduced and allocated to Industry, agriculture and allied activities on the energy sector

- Like natural disasters, there should also be a fund for a pandemic to reduce uncertainties in economic conditions and to effectively and efficiently cope with COVID-19 and similar situations in the future.

- Also, the medical and health department should focus on developing better health facilities in the district by fully utilizing their allotted funds and demand for additional funds for the development of adequate, efficient, and cost-effective health practices in the area. Medical and yoga tourism should be heavily promoted, and medical centers should be developed in the area as the provision of cost-effective medical care in collaboration with the tourism industry.

- Activity mapping should be done while policymaking by the Government because role clarity between levels of Government is essential both for efficient delivery of services and also for people to hold the different levels of governments accountable for their performance.

- The Government should also include the telecommunication sector while allocating funds at the district level so that the communication technology could reach to villages as soon as possible.

- Today in this lockdown period school education is also dependent on the technology, so the Government should sufficiently increase the budget for primary and secondary education to equip the schools as well as students with the modern ways of Education Extra funds should be allotted for the training of teachers to get along with the technological advancements.

\section{REFERENCES}

\section{Books and Research Papers}

[1]. An Analysis of State Government budget of Uttarakhand, Directorate of Economics and Statistics, Government of Uttarakhand, 2018

[2]. Financial Progress Report of various departments prepared by the Directorate of Economics and Statistics Planning Department, Government of Uttarakhand

[3]. Jasmina, Thia. (2017). The Role of Government Spending on Basic Education at the District Level in Indonesia. 25. 135-152.

[4]. Mehta G.S. (1996). Uttarakhand Prospects of Development, Indus publishing company, New Delhi. New Delhi, India

[5]. Pant H., A(2016). Guide To Using Budget Analysis, Centre for Budget and Governance Accountability(CBGA),

[6]. Policy Research Working Papers. (March 2018).The Reallocation of District-Level Spending and Natural Disasters: Evidence from Indonesia 
Budgetary Trends of Uttarakhand Government: An Analysis of Almora District

Shivani Shah, K.C. Joshi, B.P. Singhal

[7]. Rao, K.V. (2001). Research Methodology in Commerce and Management. Sterling Publication, New York.

[8]. Varshney J.C.(2007). Public Finance, SahityaBhawan Publishers and Distributors (P) Ltd., Agra

\section{Websites}

[1]. https://www.datanetindiaebooks.com/District_Factbook/Uttarakhand/Almora\#: :text=M ain $\% 20$ source $\% 20$ of $\% 20$ income $\% 20$ in,in $\% 20$ sq $\% 20 \mathrm{~km} \% 20(2019)$.

[2]. https://www.latestlaws.com/bare-acts/state-acts-rules/uttarakhand-state laws/uttarakhand-district-planning-committee-act-2007/

[3]. https://scroll.in/article/961720/free-power-easy-loans-how-uttarakhand-is-trying-to-holdback-locals-who-have-returned-from-cities

[4]. http://wmduk.gov.in/Perspective_Plan_2009-2027.pdf 